\title{
Caminhos da Dramaturgia \\ Brasileira Contemporânea
}

Entrevista com Samir Yazbek ${ }^{1}$

Quais são os impulsos cênicos e/ou mente, é que se estabeleça algum tipo de sociais que possuem mais impacto em diálogo com esta tradição, normalmente seu trabalho enquanto dramaturgo?

$$
\text { para problematizá-la. }
$$

Antes de tudo, a relação com o ator é o principal estímulo para o meu trabalho enquanto dramaturgo. Estar próximo do ator, experimentar com o ator, dirigir o ator, todas essas atividades chegam a determinar, no meu caso, o ato de escrever para teatro. Também considero o teatro como um fórum privilegiado para aprofundar questões humanas relevantes em nossa época.

Qual é a função da palavra e do texto teatral em suas montagens (ou dispositivos cênicos)?

Levando em conta que tenho dirigido algumas de minhas peças, a palavra e o texto teatral costumam nascer de um imaginário denso, para depois amadurecer a partir do contato com a cena. Não apenas a palavra, mas o silêncio, o gesto, as movimentações etc., são elementos que constituem a natureza do texto teatral.

Do seu ponto de vista, quais são as barreiras e riscos mais iminentes que a dramaturgia brasileira contemporânea precisa enfrentar?

É saudável que os autores sejam permeáveis à pluralidade de caminhos que a criação dramatúrgica contemporânea oferece, além de se deixarem contaminar por outras linguagens artísticas, sem perderem de vista o amadurecimento de suas próprias individualidades. Ao mesmo tempo, como parte de uma estratégia de valorização da palavra, é preciso evitar que a proliferação dos processos colaborativos, por todo o país, ofusque o fato de que boa parte dos textos considerados antiquados, hoje em dia, nasceu de um contato estreito do autor com a cena de sua época.

Como você vê a importância das oficinas de dramaturgia as quais você administrou e como você vê os resultados

Qual é a função e a importância da concretos delas?

tradição dramática em seu processo dramatúrgico?

A tradição dramática teve fundamental importância em minha formação, mas, hoje em dia, já não representa um modelo válido para a minha escritura, que se pauta muito mais por intuições e necessidades criativas, livres de quaisquer imposições. O que pode ocorrer, eventual-

Cada vez mais considero as oficinas que dou como extensos diálogos sobre dramaturgia, teatro, arte em geral, além de outros assuntos, como filosofia etc com o intuito de ajudar a despertar a consciência e a vontade criadora de cada aluno. Acreditar que os melhores resultados possam surgir rapidamente, só impede que os processos artísticos tenham

do Cedro". A presente entrevista foi realizada por e-mail. 
tempo suficiente para se desenvolver.

Como você vê o papel do Estado no processo de construir e consolidar uma Dramaturgia Brasileira Contemporânea?

Ainda falta muito para o Estado ocupar o seu papel de incentivar a nossa dramaturgia, por meio de oficinas, editais, montagens, publicações etc. Além disso, a política cultural brasileira, em geral, quase não se interessa em promover nossos dramaturgos no exterior. $\mathrm{O}$ que tem sido feito, neste sentido, ocorre muito mais por conta de iniciativas de indivíduos ou de instituições privadas.

Tem algo que você considera importante para complementar estas questões?

É preciso sempre lembrar que o fortalecimento de nossa dramaturgia depende não apenas do desenvolvimento de uma técnica de escrita específica, ou mesmo de fatores de ordem econômica, que asseguram a montagem dos textos, mas, sobretudo, da existência de uma visão de mundo que seja suficientemente consistente para se impor nos dias de hoje. 